Vol. 2, No. 1, 2021, pp. 19-24

DOI: https://doi.org/ 10.2921/08jces98900

Contents lists available at Џournal IICET

Journal of Counseling, Education and Society

ISSN: 2716-4896 (Print) ISSN: 2716-4888 (Electronic)

Journal homepage: https://jurnal.iicet.org/index.php/jces

\title{
Exploration of risk factors by applying respectful model among drug addicts of malay ethnic
}

\author{
Merikan Aren ${ }^{1}$, Fatin Farhanah Matjelan ${ }^{1}$ \\ ${ }^{1}$ Faculty of Cognitive Sciences and Human Development, Universiti Malaysia Sarawak, Malaysia
}

\begin{abstract}
The purpose of this research is to explore the risk factors by applying respectful Model among drug addicts of Malay ethnic in Sarawak, Malaysia. Data and information were gathered from 3 participants from CCSC, Kuching. Qualitative research methodology is used in this research and the data were collected by using group counselling sessions and audio recorded. The data were analyzed using content analysis from the group counselling sessions and applying respectful Model to achieve final results. The findings have shown that there were risk factors that affect the drug addicts based on domain from respectful Model, Psychological maturity and personal style (P), location of residences (L) and family background $(\mathrm{F})$. Another factor that affects drug addiction is peer pressure. The study contributes to the existing pool of knowledge to the pattern of drug addictions in Malaysia. In addition, it will be useful towards the authorities in identifying the specific factors affecting the drug addicts to reduce the number of relapse and drug addicts. On the other hand, the result of this study could help counsellor to understand the clients that are involved in drug addiction in depth.
\end{abstract}

(C) 2021 The Authors. Published by IICET.

This is an open access article under the CC BY-NC-SA license

(https://creativecommons.org/licenses/by-nc-sa/4.0

\section{Corresponding Author:}

Arena, M.,

Faculty of Cognitive Sciences and Human Development, Universiti Malaysia, Malaysia

Email: amerikan@unimas.my

\section{Introduction}

Based on statistics reported by Agensi Anti Dadah Kebangsaan (AADK), there were 17,474new cases and 7,793 relapse cases detected in 2018. In a total of 25,267 cases found in Malaysia, $81.8 \%$ cases come from Malay ethnic out of 6 groups reported. The statistics shown has not been added to the number of drug addicts that are yet to be reported and are still out there. In Sarawak, AADK also reported that Malay ethnic in Sarawak found the highest number of drug addicts in Sarawak which were 423 out of 693 cases.

Drug addiction is one of the top crises in the century and most painful concerns that affect social problems, safety, economic and welfare issues in Malaysia. The phenomena have affected the country since 1983 and become critical in the current era as it directly impacts the decline of ringgit and increasing health care issues of individuals. Nowadays the drug addicts have been spreading everyday through all works of life. People involved with drug addicts may come from low socioeconomic status to high socioeconomic status across gender and age. Thus, every person is potentially involved in drug addicts regardless of age, gender and position.

Based on a report of statistics by AADK (2019), statistics from 3 years ago showed that $80 \%$ of drug addicts in this country are from Malay ethnic and this year the statistics has yet to show any changes. According to 
AADK, the factors that affect the Malay drug addicts are poverty and low education level. They also reported that most of them are found living in poverty areas such as PPR area, fishing area and design land FELDA. Hence, the exploration factors that affect the drug addicts should be explored in the counselling session.

Nevertheless, the number of detained relapsed addicts are rising too. Generally, the number of drug addicts should reduce upon success of treatments or rehabilitation programs. However, the report showed that most of the drug addicts failed to maintain the drug free lifestyle after they have been discharged from the rehabilitation centre. Based on a study by Mohamad Hussain and Mustafa (2001), they reported that heroin addicts after being discharged from Serenti rehabilitation centre within six months showed $90 \%$ of cases are relapsed. Besides, morethan $70 \%$ of the drug addicts who attended drug rehabilitation centres would relapse (Habil, 2001). Although some of the rehabilitation programs had been successful, $70 \%$ to $90 \%$ of the drug addicts would probably return to the habit within the first year after being discharged (Reid, Kamarulzaman \& Sran, 2007). Thus, the rise of relapse is a bit alarming towards the country despite various efforts have been made by the government, AADK and non-government organizations. Therefore, this research was initiated to explore the factors that contribute to drug addiction among drug addicts in Malaysia.

This research is focused on exploration of factors that affect the drug addicts amongMalayethnic in Sarawak. The understanding of risk factors of drug addicts is important to overcometheraising number of drug addicts and relapse in our country. Thus, the researcher choseRESPECTFUL Model to identify the factors that affect the drug addiction of the individual. Themodel is applied in counselling sessions as it consists of 10 factors that affect the individual psychological development and personal wellbeing.

\section{Method}

The research design chosen for this research is descriptive research design. By using this design, the researcher could describe the situation on the risk factors of drug addicts among Malay ethnic in Sarawak. By implementing an in-depth research design, the researcher can provide insights into the why and how of the research. The approach used was a qualitative research approach which involved a group counselling with the drug addicts. Descriptive research design is chosen as it helps the researcher to obtain information concerning the current status of the drug addicts and to describe the risk factors by applying RESPECTFUL model in counselling session.

The participants of this research were clients who were involved with substance abuse (drug)who were located at Cure and Care Service Centre (CCSC) Kuching. The selection of participants was based on the need for research which is equivalent to exploring the risk factors by applying RESPECTFUL Model among drug addicts. The sample consisted of 3 participants from CCSC, selected by using a purposive sample method. The participants involved in this research were volunteers that met the criteria, drug addicts from Malay ethnics.

The instrument used in the process of data collection in this research was the audio recorded in each session and the data was taken and added in the counselling report. The audio recorded of each session was including the aspects such as voices of participants and counsellors and overall responses of the participants in the session. This method helped the researcher to enhance the findings.

The information and data collected through the counselling sessions were confidential. In this study, there were two main ethics that have been highlighted. These were confidentiality and informed consent. Confidentiality refers to information obtained about a participant during an investigation. Another ethics was informed consent that refers to every research project that uses human participants should have an informed consent form that is read and signed by each participant. Before the group counselling session was conducted, the informed consent form was given to all the participants involved in this research. The participants were informed earlier on the objectives of the study. The collection of data in this research is divided into three stages. The first stage is obtaining informed consent and selecting participants. In stage two, a group counselling session was conducted for two counselling sessions. The last stage is recording the data collected.

In this first stage, the researcher had written a letter of consent to CCSC Kuching to obtain permission to do counselling sessions with clients. The selection of the participants proceeded once approved. Then, two sessions of group counselling with three participants were held at CCSC Kuching. Group counselling session was a method to explore issues by discussion and expressing feelings with the members and the counsellor. An overview of the counselling session was the exploration of risk factors by applying RESPECTFUL Model in the session. Once the data was collected from the group counselling sessions, the data was analyzed to answer the research questions of this study. Besides, data from past researches were collected from journals and reading materials to get complete and valid results. 
Data and information were collected based on the interview during the group counselling sessions with the participants. The data were analyzed by using content analysis. Thus, the data obtained from the counselling session was analyzed to obtain the findings of the study. The qualitative research design used the researcher's understanding and knowledge to convey meaning and interpret the meaning based on what the participants explained. The data obtained was carefully analyzed to avoid any changes in meaning or omission of the main content described by the participants.

The data obtained from the session were transcribed. Then, the data were given meaning based on the reading material that has been read to understand the implicit and explicit meaning that was conveyed by the participants. Moreover, the recorded audio was analyzed. Every information that has been recorded was transcribed and categorized based on the objectives of the study. Then, the data were arranged and analyzed. In addition, all the information obtained from the group counselling session were transcribed. The transcript was used to assist the researcher for review and refer in writing a report.

\section{Result and Discussion}

Based on data and information gathered, the researcher was able to find risk factors of each participant from the group counselling session. The factors that affected Participant 1totake drugs were curiosity, peer pressure and residential area. Based on his explanation, he seemed unable to control himself when he unconsciously paid for the drug at his first time using drugs. Besides, the researcher found that Participant 1 had strong interest to challenge himself to try drugs when he saw his peers were doing it. Thus, the participant 1 was feeling pressured when everyone but him was taking drugs. Moreover, another factor that affected participant 1 was residential area. This factor was found when the participant 1 first time using drugs was at his residential area with his peers.

\section{"Kamek pun pandai keluarduitmokcuba..." (Participant 1).}

Meanwhile, the factors that affected Participant 2 to take drugs were curiosity, peer pressure, work environment and residential area. The researcher found that Participant 2lackedself-control when his surroundings, from his peers and colleagues at work were drug addicts. He seemed to easily attract with the activity as throughout his adolescent years he was watching elders taking drugs near his house. Thus, he seemed to recognize the activity and seemed to have a high tendency to try it out himself at a later age. Furthermore, a factor that affects participant 2 to be involved in this activity was feeling pressure with colleagues at the workplace. The researcher found that the participant 2 seemed to be an impressionable person as he easily swayed by his peers' words.

"Hari-hari nangganya masang bendaya, masuk rah badan. Jadi kamek pandeinginjuak. Cobalok. Nakcubagine rasa." (Participant 2).

While for Participant 3, there were three factors that affected him to take drugs, curiosity, peer pressure and work environment. The researcher found that participant 3 also seemed unable to control himself from trying out the drugs. The participant 3 seemed to get attracted by this activity from his friends when they hangout. Besides, the researcher found that participant 3 wasinvolved in drug addicts because of his job scope at work. The participant 3 seemed to have done heavy work before and that led him to take drugs which he thought would help him productively. Thus, the participant 3 seemed to take drugs because of his workload and to have better work performance without realizing the side effects.

\footnotetext{
"Dah hari-harikeluaya mala nengoksidak main... rasa ingincubayanangtinggilah" (Participant 3).

"Bila shift kerjamalamyanangbagusmenalah...prestasibaguslah..."(Participant 3).
}

Based on the RESPECTFUL Model, the results of the analysis from this study showedthat the main domain contributor that affects the drug addicts is Psychological maturity or personal style $(\mathrm{P})$. Based on the participants' explanation, they seemed unable to control themselves fromtaking drugs when they saw peers and people around them were taking it. Besides, theparticipants also seemed to have a high level of curiosity to try it on their own. Thus, theparticipants lacked self-control, which they were unable to control their strong interest towardsdrugs. Therefore, the researcher found that their personality is the main factor that contributestotheir drug addiction.

Another factor that found from this study based on the RESPECTFUL Model is Locationof residence (L). The researcher found that this factor is the second highest as all of theparticipants seemed to take drugs for the first time in their residential area. Thus, the locationoftheir living plays an important role in an individual life 
as it is a place where people growupandplay around. The researcher found that the participants seemed like they noticed the legal activityin their residences earlier since they were children, however unknowingly got involvedthemselves later on.

"Benda yamacamnang dah adakatsia... siktauk sine datang" (Participant 2).

Moreover, based on analysis by applying the RESPECTFUL Model, another factor that can be found from domain Location $(\mathrm{L})$ is the work environment factor. The researcher foundthat the work environment plays a role in affecting the participants to involve drug addicts. Thisfactor is categorized in domain Location as the work environment includes, the workload, conditions and colleagues in the workplace. The participants seemed to take drugs to helpthemwork efficiently and improve their work performance at the workplace. Moreover, theparticipants admitted that they felt energy rose up when they took drugs before work. Theresearcher also found that participant 2 explained the effects of taking drugs as he couldlift upheavy objects. In addition, the research also found that the pressure from colleagues whoweredrug addicts had influenced the participants. Therefore, this domain is one of the factors that affect drug addicts.

"Bila shift kerjamalamya, nang bagus menalah. Kesannyanangadoh. Prestasi baguslah." (Participant 3). The present study was carried out to study the profile of Malay ethnic in Sarawak that involved drug addicts. Findings demonstrate that participants came from suburban areas which were near to the cities. Besides, findings also showed that all participants had low academic and low stable income. Studies suggest that half of the drug addicts detained in the CCRC came from the cities as they had easier access to drugs (Yahya Buntat \& Dzulkhissam Rahmat, 2015). Based on the same studies, individuals who had low academic and religious education are more involved in drug abuse compared to those who had high academic and religious education. The level of education for all of the participants from this research were certified at SPM level and this result can be supported by the same study that showed most drug addicts detained in CCRC in whole Malaysia were mostly certified at SPM, PMR and primary school level. The results from the present study showed similar findings with the past study from Yahya Buntat and Dzulkhissam Rahmat (2015).

The present study was carried out to study the main domain of factors that affect drug addicts' individuals based on the RESPECTFUL Model. The result obtained from this study indicated that risk of drug addiction among Malay ethnic is multifactorial. Drug addiction is influenced by a diverse set of risk factors either external or internal. The present study showed that the main domain contributor that affects the drug addicts is Psychological maturity and personality style $(\mathrm{P})$ based on the RESPECTFUL Model. In addition, there were also two factors found and analyzed, which were Location of residences (L) and Family background (F).

In this study, the main domain contributor is psychological maturity and personal style. Findings showed that the factor that affected them involved in drug addicts was curiosity. All of the participants seemed to have lack of self-control and high interest to try out new things. This is supported by studies, which AADK reported that the second highest factor that drives a person to engage in drug abuse is curiosity in 2018 (AADK, 2018). Curiosity is helpful if used in a proper setting such as in education. However, in this context, high levels of curiosity in the wrong setting contribute to addiction and disasters. Based on the RESPECTFUL Model, Psychological maturity involves an individual's stage of cognitive and emotional development which relates to the acting stage skills. This domain highlighted a process of individuals moving from simple to more complex ways of thinking about themselves and experiences. Thus, the factor of curiosity and lack of self-control are categorized in this domain. The results showed that all of the participants showed curiosity was one of their main factors to get involved in drug addiction. Awareness programs should be organized regarding the harmful effects of taking drugs and getting addicted to it. The public should be aware of the consequences of drug addiction so that they would stop before curiosity ruins their life later.

Another factor that affects the individuals involved in drug addicts is the residential area and work environment. Based on the model, the factor can be categorized in the domain of Location of residences (L). Findings demonstrate that all of the participants showed location of their residences and their work environment had affected them to become drug addiction. Apparently, an individual growing up in a certain environment has a strong impact on his or her later development. In Erikson's psychosocial development, a person should fulfil each stage of eight predetermined stages. A person who comes from a dysfunctional family could not obtain what is needed at a certain stage, he or she gets stuck and causes behaviour issues in life. However, it is recommended to further research to validate the impact of growing up in an environment on a person's later abuse behaviour. Besides their residences, the work environment is also one of the factors in this domain of location of residences. The work environment factors that are always prone to fatigue and need more energy are also present by the participants. A lot of energy is needed to work and due to that the participants had to take a certain amount of methamphetamine before starting the job. The use of 
methamphetamine causes a further increase in a long time in brain endurance and limbs as well as social interactions (Brown, Wise \& Kiyatkin, 2003) have supported the findings of studies on drugs as a source of energy strength.

The present study also investigates that family factor and peer pressure contribute to drug addiction of the participants. Family and friends play an important role in the first drug use experience. The findings demonstrated that having family issues has resulted in their relapsing and taking drugs. The findings can be supported by a research that found the low level of communication, loose and limited interaction in family causes a high tendency for addicts to get back in touch with the same peers of addicts (Mohd Taib, Rusli and Mohd Khairi, 2000). Thus, family factor in this study can be categorized in the domain of Family background (F) in the RESPECTFUL Model. In this context, it is important for the counsellor or the researcher to understand the unique strengths that the client derives from the family system. Understanding the family background of drug addicts is a vital approach to get in depth about their experiences in addiction that may involve their family history.

Apart from family factors, the findings of the current study showed that peer pressure is one of the risk factors that contribute to drug addiction. According to the statistics by Agensi Antidadah Malaysia, the peer influence is the major contributory factor of drug abuse which is $57.9 \%$. The present study showed that the participants seemed pressured and conformed to their peer group as their friends were all taking drugs. This seems to be in line with research that showed people are prone to misuse drugs when they see peers doing it (Verkooijen, Vries\& Nielson, 2007). The constant interaction for and enhancement of peers who are drug addicts may predispose others to use drugs more readily. In this study, it shows how impactful friends are to a person even though they do not directly instruct the person to act negatively. Hence, parents play an important role in always being aware of whom their children interact with.

\section{Conclusions}

Base on result, All of the participants showed a positive response during each session throughout the two sessions conducted for this research. Besides that, the limitations of this research are limited time to conduct in depth study and the readiness of the participants. Moreover, this study is also limited to the researcher's knowledge on drug addicts' issues. Therefore, the researcher should be more aware and prepare themselves with input about drug addicts' issues to understand the participants better. As this study showed a positive result, it is suggested that future researchers can conduct this study using the model and the same setting or indifferent setting. In addition, future researchers may combine the approaches and methods used to obtain more information and accurate results. In a nutshell, the current research provides us a general idea of the risk factors that affect the drug addicts of Malay ethnic in Sarawak by applying the RESPECTFUL Model, providing clues to related parties on how we can further work on reducing and eliminating drug abuse and addicts in our country.

\section{References}

Agensi Antidadah Kebangsaan. (2007). Maklumat dadah. Retrieved fromhttp://www.adk.gov.my.

Agensi Antidadah Kebangsaan. (2019). StatistikDadah. Retrieved fromhttps://www.adk.gov.my/orangawam/statistik-dadah/

Azizul, D., Wan Jaafar, W. M., \&MohdKhir, A. (2018). Faktor Luaran Relaps Dalam Kalangan Penagih Lelaki Dewasa di Cure and Care Service Centre, Kuala Pilah. Malaysian Journal ofSocial Sciences and Humanities (MJSSH),3(2), 159 - 168.

BuerahTunggak, ShahrinHashim, NurAfzan Mohamed, and Maznah Ali (2015) Faktor Risiko Belia Terlibat Dalam Penyalahgunaan Dadah dan Cadangan Penyelesaiannya Menerusi Model Pembangunan Belia Muslim Terpimpin. Journal Antidadah Malaysia, 9(1).

ChuahMooi Kim. (1990). Keyakinan Diri Penagih Dadah: Hubungannya Dengan Sokongan Sosial dan Faktor Demografi. Latihan Ilmiah. Bangi: Universiti Kebangsaan Malaysia.

Clarke R. (1993), Profiling: A Hidden Challenge to the Regulation of Data Surveillance. Publishedin the Journal of Law and Information Science 4(2) (December 1993).

D'Andrea, M., \& Daniels, J. (2001). Respectful counseling:An integrative model for counselors. In D. PopeDavis \& $\mathrm{H}$.

Gupta S, Kulhara P. Cellular and molecular mechanisms of drug dependence: An overview and update. Indian J Psychiatry 2007, 49(2): 85-90.

H. Habil, M. Ali Mohd, Penyalahgunaan Dadah Hidup Tidak Beerti Maut Menanti (Dewan Bahasa dan 
Pustaka: Kuala Lumpur, 1999) 2. N. M.

Habil, H. (2001). Managing heroin addicts through medical therapy. Kuala Lumpur: University Malaya Press.

Ibrahim, F., \& Kumar, N. (2009). Factors effecting drug relapse in Malaysia: An empirical evidence.Asian Social Science,5(12), 37-44.

Kalivas PW. Neurocircuitry of addiction. In Davis K.L., Charney D., Coyle J.T., Nemeroff C. (eds.)Neuropsychopharmacology: The Fifth Generation of Progress, American College of Neuropsychopharmacology, 1357 - 1366, 2002.

LeBeauf, I., Smaby, M., \& Maddux, C. (2009). Adapting counseling skills for multicultural anddiverse clients. In G. R. Walz, J.C. Bleuer, \& R. K. Yep (Eds.), Compelling counseling interventions: VISTAS 2009 (pp. 33-42). Alexandria, VA

Mahmood Nazar Mohamed, MohdShuibChe Din, LasimonMatokrem, Muhamad DzahirKasa\&Rusli Ahmad. (1999). Penagihan Dadah dan Residivisme: Aspek-Aspek Psikososial dan Persekitaran. Kedah: Pusat Penyelidikan dan Perundingan, UniversitiUtaraMalaysia.

Mc Coy. C. B \& Lai. S. (1997). No Pain, No Gain, Establishing the Kunming, China, Drug Rehabilitation Center. Journal of Drug Issues. 27 (1):73-85.

Mohamad Hussin Habil\& Mustafa Ali Mohd. (2001). Managing drug addiction: mission is possible. Ampang: Penerbitan Salafi.

Mohd Khairi, Amir Faisal and Abdul Rahman, Hejar and Muthiah, Sri Ganesh (2017) Risk factorsof drug abuse among Malay males FELDA settlers in Jerantut, Malaysia. Journal of Substance Abuse and Alcoholism, 4 (5). pp. 1-9. ISSN 2373-9363

Mohd Rafidi. (2008). Rancangan Pemulihan Klien: Asas dan Aplikasi Untuk Profesional Pemulihan.Jurnal Anti dadah Malaysia, (3) \& (4), 57-73

Mohd Taib \& Mohd Khairi. (2000). Pola-pola Komunikasi Kekeluargaan: Kajian di kalangan Keluarga Penagih dan Bukan Penagih di Negeri Kedah. Penyelidikan Sekolah Pembangunan Sosial.

Mohd Taib, Rusli \& Mohd Khairi (2000). Pola-pola Komunikasi Kekeluargaan: Kajian di kalangan Keluarga Penagih dan Bukan Penagih di Negeri Kedah. Penyelidikan Sekolah Pembangunan Sosial.

Piko (2000). Perceived social support from parents and peers: which is the stronger predictor ofadolescent substance use? Substance use Misused, 35(4), 617-30

Reid, G., Kamarulzaman, A. \& Sran, S.K. (2007). Malaysia and harm reduction: The Challenges and Responses. International Journal of Drug Policy, 18(2), 136-140.

SaedahSiraj (2000). Remaja dan Strategi Penyelesaian Masalah. Universiti Malaya: Alam Pintar Enterprise.

Tam, C. L., \& Foo, Y. C. (2013). A qualitative study on drug abuse relapse in Malaysia: contributory factors and treatment effectiveness. International Journal of Collaborative Researchon Internal Medicine \& Public Health,5(4), 217 - 232.

Verkooijen, K. T., de Vries, N. K., \& Nielsen, G. A. (2007). Youth crowds and substance use: Theimpact of perceived group norm and multiple group identification.Psychology of AddictiveBehaviors, 21(1), 5561.

Watts, W. D., \& Wright, L. S. (1990). The drug use- violent delinquency link among Mexican-Americans. In M. De La Rosa, E. Lambert, \& B. Gropper, Drugs and violence: Causes, correlates and consequences. NIDA Research Monograph. Maryland: National InstituteonDrug Abuse.

YahyaBuntat, DzulkhisshamRahmat@ Rahaman. (2015). Profil Penagihan Dalam Kalangan Penagih Yang Ditahan Di CRCC Seluruh Malaysia. Retrievedfromhttps://www.adk.gov.my/wp-content/uploads/3Artikel-Profil-Penagihan-dan-Jenis-Kesalahan-UTM-min.pdf

YunosPathi Mohamed. (1996). Dilema, Pengalaman dan Prospek Bekas Penagih Dadah. Kertas Kerja Seminar Dari Institusi Pemulihan Ke Pangkuan Masyarakat, AnjuranYayasan Pencegahan Jenayah Malaysia. Hotel Crown Princess, Ogos 1996 